\title{
The Evangelical-Lutheran Church in South Africa: an introduction to its archival resources held at the Lutheran Theological Institute (LTI) Library, and the challenges facing this archive (Part Two).
}

\section{Francis Garaba and Annalise Zarvedinos}

\begin{abstract}
The challenges confronting the LTI Archive are the subject of Part Two of this series of articles. To recap, the first part of this instalment gave an insight into the evolution of the LTI Archive in the context of the history of the Lutheran church in South Africa. The archival management aspect of the documentation created during the formative period and until the present will be the focus of this paper. A plethora of issues will be looked at. These include, inter alia, the building holding the collection from a preservation point of view and the measures currently underway to safeguard this ecclesiastical heritage, considering that mission archives such as this one hold information that is important from not only an historical, but also an ethnological, sociological and theological point of view.
\end{abstract}

Keywords: Lutheran Church; Church history - South Africa; Church archives; archival practice

\section{The Management of the LTI archive}

Arising from the historical bodies and events outlined in Part One of this series of articles, a collection of documents relating to missionary work, theological training and administrative history of the Lutheran church is now in the custody of the LTI archive. The material in custody is undergoing processing, arrangement and cataloguing, with the hope of digitizing the descriptive media as well as the archival documents themselves in the foreseeable future. This digitization and its subsequent online provision will help the library in its publicity campaign. Theimer (2011:123) observes that most archival institutions have realized the value of using the Web to publish information about themselves and their collections - usually in the form of putting finding aids online.

In the same vein, Convery (2011:199) rightly points out that engagement with the user is probably the most prevalent shift in the digital world. Considering that users are voting with their fingers in cyberspace (Cunningham 2011:182), the community expects its information sources to be available online and increasingly regards anything that is not online as being irrelevant. In consequence, this means that documentation centres, be they libraries, archives or museums, should move with the times in search of both permanence and relevance in this digital era. 
At the LTI Archive as pointed out in Part One of this paper, documents relating to individual staff members, students, pastors, and their papers and research, as well as to institutions, associations, curricula, conferences, student bodies, applications, welfare etc, minutes of meetings, reports, societies, committees, records of appeal and adjudication, interoffice memos, appointment books, registers, charters, constitutions and bylaws, legal papers, deeds, articles of incorporation, agreements, financial ledgers, and various other papers pertaining to the different churches or missions are included in the files. In addition, the archival repository also maintains a historical depository of denominational journals, periodicals, convention proceedings or transactions pertaining to the Lutheran Church in South Africa. In a nutshell, the archival repository serves as an adjunct to the theological library thereby serving as a rich resource of primary material on the history of the Lutheran Church in the country. The importance of scholars using primary material cannot be overstated for the simple reason that these documents bring one close to the originating experiences.

The LTI Archive houses documents all of which came from the Lutheran Theological Seminary (LTS) at Umpumulo. As noted above, the papers that came to the LTI from Hermannsburg/Evangelical Lutheran Church in Southern Africa (ELCSA), from Northern Transvaal (N-T)/United Evangelical Lutheran Church in Southern Africa (UELCSA) as well as the documents that have been in the LTI since it began to be administered by the South African Lutheran Theological Training Trust (SALTTT), are already undergoing processing and will be treated as separate bodies of historical documents. Due to the lack of archival policy however, the LTS as it was known then, collected denominational resources unknowingly or by accident. This runs counter to the recommendations of archivists and as Saffady (1974:204-205) notes, the effective and efficient management of records must be supported by an infrastructure of policies, structures, procedures, tools, training and resources. It is for this reason that the Archives/Manuscript Unit of a library must derive its authority from a policy statement or charter issued by library management, setting out the objectives and mapping out the planned programme (Mnjama 2006:115). Ideally, this policy statement should be approved by the library management and issued in the form of a directive. It should specify the need for the programme, the objectives, the proposed structure of the programme and the level of administrative and technical support required (Mnjama 2006:114).

Mnjama (2006) further notes twofold reasons as to why libraries with manuscript collections need to formulate such a policy. In the first instance, resources must be allocated for running the archives programme. Secondly, the establishment of the post of an archivist within the library set up must be approved by the library management and an administrative framework established. The LTI's management, through SALTTT, has been very supportive in this regard and the appointment of a manuscript librarian in early 
2011 underscores the fact that the management has realized that this recorded information needs to be managed professionally for it to remain accessible. The duties of the manuscript librarian include inter alia, developing an understanding of how to undertake the following:

- $\quad$ Arranging and cataloguing archival material;

- $\quad$ Storing and preserving archival material;

- Disseminating archival material.

Unfortunately, most of the documents are stored in a room that lacks structural conditions for the preservation of paper as it was not purpose built as an archive. Thus, until recently the substantial written heritage of the Lutheran Church was dangerously exposed to the threat of enhanced decay. To remedy this situation, the library staff have been processing the archival heritage and storing it in acid free boxes in order to preserve the useable life of the information contained therein. This creation of a microenvironment has been the best solution to compensate for the lack of technical measures usually associated with an archival institution. In addition, a disaster plan is in place as part of emergency preparedness.

\section{The building}

Ritzenthaler (1993) points out that the highest preservation priority of every archival institution should be to provide environmentally controlled quarters for the storage and use of its holdings. This is a mass preservation approach that benefits all items in a repository. A heating, ventilating and air conditioning (HVAC) system, though expensive to install and maintain, is the most cost-effective means of caring for collections. The Lutheran Theological Institute (LTI) library building has this facility, though it was not specifically designed to store archival materials as it lacks the architectural specifications synonymous with purpose-built/custom built buildings. The archives storeroom is a partitioned room adjoining the main library building and the use of the centralized air-conditioning for heating and cooling uniformly affects books, audio-visual and archival material.

This situation is not ideal considering the strain that the fluctuations in temperature and relative humidity subject archival material to. In an effort to address this situation, staff has had to create favourable conditions for the records by trying to provide a microenvironment by the use of acid free boxes. Millar (2010) rightly notes that archival quality envelopes, folders and boxes produce a stable microenvironment, reducing the spread of acid and mitigating the effects of fluctuating temperatures and relative humidity. This strategy has its limitations though, especially from an economic point of view. The cost of housing large volumes of archives in acid-free containers can be very high and the folders and boxes will very likely need to be replaced every few years, as the acid documents will leach out onto the surrounding materials, diminishing their stability (Millar 2010). 
The collections at the LTI archives are also vulnerable to fire as the building is not custom built as earlier noted. Although the library has fire extinguishers, there has not been any investment in fire detection devices such as smoke and heat detectors and fire control panels. Hunter (2003:192) notes that fire extinguishers are only effective as fire suppression devices if the fire is small and detected at an early stage and if there are people present at the scene to operate them. Wet-pipe and dry-pipe automatic sprinklers are the most reliable and safest fire extinguishing methods available, but their disadvantages include the higher installation and maintenance expenses. For a small library like ours, these installation and maintenance costs are beyond reach. To get around this problem, our best strategy has been co-operation with the local fire department to conduct fire drills and staff training.

\section{Disaster planning}

Disaster preparedness and security of collections be it in libraries or archives, both public and private, has never been prioritized. Ngulube (2005; Ngulube and Magazi 2006) observe that many libraries and archives in east and southern Africa have neither a disaster preparedness nor a security plan in place. In fact, too many librarians and archivists in the region have not even given serious thought to or put any effort into the development of any such plan. Against this background, it became imperative to come up with the present plan at the LTI Library in an attempt to address the need for emergency preparedness.

Millar (2010:87) correctly states that an emergency response plan identifies potential emergencies and categorizes their potential danger to the institution and holdings. Disasters can be natural or man-made and there is consensus that a good plan makes an incident much easier to manage and helps individuals to make decisions quickly and assess the situation at hand effectively and efficiently. Plans minimize risk, maximize the speed of recovery and help the organization get back into business quickly (Mansell 2003:4; Ngulube and Magazi 2006:111). Lyall (1995) defines the disaster preparedness plan as a document which describes the procedures devised to prevent and prepare for disasters as well as those proposed to respond to and recover from disasters when they occur. Its four major components are: Prevention; Preparedness; Response; Recovery.

The plan on its own will not deal with disasters (Mathews 2009) and people therefore need to know what to do with it, what their roles are at particular stages or as regards specific aspects, and this calls for training. Management support is thus critical at all stages and the plan will need to be tested, reviewed and updated, otherwise it will be a file sitting on the shelf:

If people don't own their plan, invest in it, it won't work (US Museum and Library; cited in Mathews 2009) 
To endear the LTI's stakeholders to the goal of this plan, it is part of our strategic mission to sell the idea to staff by not only embarking on a public relations campaign (of which the present article forms a part), but to also place emphasis on the need for training in order to achieve our objective. To date, about $80 \%$ of the work for the plan has been done and much of the documentary work has focused on laying down the logistics of the plan by looking at the following (Millar 2010:88):

- Detailed evacuation procedures, including information about emergency meeting points as well as maps and diagrams;

- Floor plans for the building, identifying the locations of power and water supplies, drains, emergency exits and other critical areas;

- Full contact information for all staff who may need to be involved in an emergency response, including information about who will be responsible for making decisions and authorizing actions;

- Contact information for any organizations or suppliers who have agreed to provide emergency support, such as companies that will provide salvage services;

- The identification and location of particularly valuable or fragile items or materials that need to be given high priority during recovery operations; and

- A list of emergency equipment and materials held in the institution, with their location clearly marked.

The rehearsal of the plan is earnestly being looked forward to as it will test the institution's readiness for an emergency, but it will only be conducted once all the intricacies of the plan have been ironed out.

\section{Arrangement}

Hedenskog (1987:1) correctly observes that a well organized church archive reveals to the younger generation their religious identity. It could also be added that such an archive inspires confidence in the users and in society at large that the material is being well looked after and that the accessibility of information is guaranteed in the long term. The principle of provenance is a cornerstone of archival arrangement and it emphasises the importance of respecting the entity of the individual, family or organization that created or received the items that make up a unit of archival materials (Millar 2010:98). Provenance is defined as the origin or source of something or as the person, agency or office of origin that created, acquired, used and retained a body of records in the course of their work or life. 
Millar (2010) further notes that in order to preserve the provenance of groups of archival material, the archivist does not put together archival materials that have come from different creators or have distinct and separate origins. Hence, the integrity and unity of the archival body must be ensured in order for the individual items to reveal not only their own content, but also their role in the overall organization by which they were originally produced or used. In order to maintain the integrity of LTI Archive's collection and to reflect its provenance, it is divided into three broad groups: the papers which came from the LTS at Umpumulo; the papers which came mainly from ELCSA-Hermannsburg, ELCSA-NT and UELCSA; and the papers generated at the LTI under SALTTT. It should once again be noted that only the papers from Umpumulo, ELCSA General Assembly minutes and Diocesan Church Council minutes have thus far been processed.

\section{Access}

The aim of an archive is not only to take care of the material housed therein, but also to ensure that researchers and the general public are able to locate and access whatever items are of interest to them. It therefore follows that the ability to make collections available to users should be one of the cornerstones of a successful archival management policy. Use is the goal of all archival endeavour (Harris 2000:24) and the Canadian Archivist Timothy Ericson (1990-91: 116) remarks that:

... if, after we brilliantly and meticulously appraise, arrange, describe and conserve our records, nobody comes to use them, then we have wasted our time.

To highlight the importance of access, the Professional Code for South African Archivists (1993:106) begins a definition of the archival mission as follows:

The archivist is responsible for ensuring the availability and use of permanently valuable archives by identification, acquisition, description and preservation. Accountability to the archives creator, employer and user should shape the performance of these tasks.

Consequently, the Lutheran Theological Institute Archive is organized into about 25 different groupings broken down according to subject. Much of the broader framework of the Lutheran church's mission to Southern Africa is located within the documents belonging to the various church bodies (the Co-operating Lutheran Mission (CLM), Evangelical Lutheran Church in Southern Africa (ELCSA), Federation of Evangelical Lutheran Churches in Southern Africa (FELCSA etc.) and the papers of the Lutheran World Federation. Included in these are all of the minutiae one expects to find connected with the church: official policy statements to govern work in 
foreign fields, minutes and reports of meetings, legal documents, committee reports, official budgets, expenditures and administrative correspondence. In an endeavour to unlock the contents of the archival repository by promoting access, the librarians have compiled a database or list of the archival collections in custody and this will shortly be made available online for remote access.

This database is presently the institution's finding aid and is in electronic format found on a memory stick and also stored on the library's hard drive as back-up. The database provides the researcher with a general but comprehensive knowledge of the holdings in the repository and once $\mathrm{s} /$ he has identified the needed material, the manuscript librarian proceeds to retrieve the record/s on his/her behalf. Users are not allowed in the repository and once they are given the material, they use it without supervision due to the layout of the library. The archive is an adjunct to the library and the building was not custom built and consequently, a search room in which users carry out their research under close circuit television (CCTV) is non-existent. To safeguard the records from mutilation, destruction or theft, the librarians meticulously check material before returning it to the repository once the user is done. Ideally, this is not standard practice but due to circumstances, we have to compromise, albeit reluctantly. In view of the negative effects of light on paper, photocopying of documents is strongly discouraged.

Be that as it may, apart from conventional documents such as reports, minutes, correspondence, memoranda, the archive also contains a substantial number of slides, banners, posters, and other graphic and artistic material.

This overview of the archives at the Lutheran Theological Library serves to highlight the richness of the ecclesiastical heritage that the institution is fortunate to be endowed with. Protecting this heritage from harm and ensuring that it is available for use as long as possible are essential archival responsibilities (Millar 2010:74) and in view of this, an important measure in safeguarding this collection is the ongoing creation of a microenvironment, as mentioned earlier on. Another equally significant measure that the LTI library has adopted is the need to establish a disaster plan to mitigate unforeseen eventualities. This contingent measure is in its final phase and a rehearsal of the plan will be undertaken once the details have been concluded.

\section{Conclusion}

The Lutheran Theological Institute Archive remains a key source of information on the Lutheran church in South Africa. With 669725 Lutheran church members across South Africa in 2010, and almost 19.5 million in Africa (Lutheran World Information 2011), this church forms an important 
part of the Christian landscape in the country and on the continent. This once again highlights the value of the archival collection of the LTI. In an endeavour to unlock the contents of the archival repository by promoting access as earlier noted, the librarians have compiled a database or list of the archival collections in custody and this will shortly be made available online for remote access. Unfortunately, for one to explore this documentary collection, one will still need to physically undertake an onsite visit to get access to the original stuff. However, the LTI library staff plan to eventually digitize the entire archival collection and place it online for world-wide access. Nonetheless, as Cunningham (2011:182) aptly remarks, despite the explosion in online access to archives, physical custody of holdings remains the stated preference of the overwhelming majority of archival programmes, both for traditional format and for digital records.

\section{Bibliography}

Brandt, H. 1988. Outside the camp: a collection of writings by Wolfram Kistner. Johannesburg: South African Council of Churches.

Carruthers, S.L. 2000. The media at war: communication and conflict in the twentieth century. London: Macmillan Press Ltd.

Convery, N. 2011. Information management, records management, knowledge management: the place of archives in the digital age, in The future of Archives and Recordkeeping: a reader edited by J. Hill. London: Facet Publishing.

Cunningham, A. 2011. The postcustodial archive, in The future of Archives and Recordkeeping: a reader edited by J. Hill. London: Facet Publishing.

Durrani, S. 2000. Returning a stare: people's struggle for political and social inclusion. Progressive Librarian 17: 1-29.

Ericson, T. 1990-91. Pre-occupied with our own gardens: outreach and archivists. Archivaria 31:114-122.

Harris, V. 2000. Exploring archives: an introduction to archival ideas and practice in South Africa. Pretoria: National Archives of South Africa.

Hedenskog, S. 1987. How to arrange archives. Uppsala: Church of Sweden Mission.

Hunter, G.S. 2003. Developing and maintaining practical archives: a how-to-do-it manual. 2nd ed. New York: Neal-Schuman.

Lutheran World Information. 2011. Membership figures for 2010. http://www.lutheranworld.org/lwf/wp-content/uploads/2011/03/LW F-Statistics-2010.pdf (6 September 2011) 
Lyall, J. 1995. Disaster planning for libraries and archives: understanding the essential issues, in Proceedings of the Pan-African Conference on the Preservation and Conservation of Library and Archival materials, edited by J. Arnoult, V. Kremp and M. Musembi, held in Nairobi on June $21-25,1993$. The Hague: IFLA.

Mansell, H. 2003. The disaster control plan, in Disaster management for libraries and archives edited by G. Mathews and J. Feather. Aldershot: Ashgate.

Mathews, G. 2009. Disaster management in archives, libraries and museums. Farnham, Surrey: Ashgate.

Millar, L. 2010. Archives principles and practices. London: Facet Publishing.

Mnjama, N. 2006. The management and administration of manuscript collections within library environments in Eastern and Southern African Region, in Librarianship as a bridge to an information and knowledge society edited by A. Mcharazo and S. Koopman. IFLA Publications 124. Munchen: K. G. Saur.

Ngulube, P. 2005. Preservation and access to public records and archives in South Africa. University of Natal: PhD thesis.

Ngulube, P. and Magazi, L. 2006. A stitch in time saves nine: emergency preparedness in public libraries of KwaZulu-Natal, South Africa. Innovation 32: 110-124.

Norwegian Missionary Society (NMS) Archives 2007. Photographs back to South Africa, Catalogue No. 5: Series-07: Ekombe area. Stavanger, Norway: Norwegian Missionary Society (NMS) Archives.

Professional Code of South African Archivists 1993. South African Archives Journal 35: 106-109.

Ritzenthaler, M.L. 1993. Preserving archives and manuscripts. Chicago: The Society of American Archivists.

Saffady, W. 1974. A library archives and records management programme: some operational guidelines. College and research Libraries 35 (3): 204-210.

Theimer, K. 2011. Interactivity, flexibility and transparency: social media and Archives 2.0, in The future of Archives and Recordkeeping: a reader edited by J. Hill. London: Facet Publishing. 